\title{
Solar PV fed non-isolated DC-DC converter for BLDC motor drive with speed control
}

\author{
G. G. Raja Sekhar'1, Basavaraja Banakar ${ }^{2}$ \\ ${ }^{1}$ Department of Electrical and Electronics Engineering, , K L E F, Vaddeswaram, Guntur, A.P., India. \\ ${ }^{2}$ Department of Electrical \& Electronics Engineering, University of BDT Engineering College, Davanagere, Karnataka, \\ India.
}

\begin{tabular}{l} 
Article Info \\
\hline Article history: \\
Received Jul 2, 2018 \\
Revised Nov 6, 2018 \\
Accepted Nov 16, 2018 \\
\hline
\end{tabular}

Keywords:

BLDC motor

Interleaved Boost Converter

Solar photo-voltaic

Speed control

\begin{abstract}
The paper presents an efficient speed control of brushless DC (BLDC) motor drive for solar photo-voltaic (PV) system fed system. An interleaved boost converter is employed in the system to boost the solar PV system low output voltage to a level required for the drive system. Interleaved boost converter is operated in closed-loop mode to attain accurate and steady output. The converter (VSI) for BLDC is switched at fundamental frequency and reduces high frequency switching losses. Internal current control method is developed and employed for the speed control of PV fed BLDC motor by sensing the actual speed feedback. The appropriateness of the internal current controller for the speed control of PV fed BLDC motor is verified for incremental speed with fixed torque and decremental speed with fixed torque operating conditions. Also the system with speed control is verified for variable torque condition. The system is developed and results are developed using MATLAB/SIMULINK software.
\end{abstract}

Copyright $(0) 2019$ Institute of Advanced Engineering and Science. All rights reserved.

\section{Corresponding Author:}

G G Raja Sekhar,

Department of Electrical and Electronics Engineering,

Koneru Lakshmaiah Education Foundation,

Green Fields, Vaddeswaram,

Guntur District, A.P., INDIA. Pincode: 522502

Email: rsgg73@gmail.com

\section{INTRODUCTION}

The Development in power electronic section of electrical engineering has led to developments in special machines and one such kind is brushless DC (BLDC) motor. The construction of brushless DC motor is quiet similar to that of conventional DC motor but the absence of brush-commutator assembly makes BLDC motor more efficient in operation. The BLDC motor is electrically commutated by power switches instead of brushes. Compared with a brushed DC motor or an induction motor, the BLDC motor has many advantages: Higher efficiency and reliability, Lower acoustic noise, Smaller and lighter construction, Greater dynamic response, Better speed versus torque characteristics, higher speed range, longer life. A rotor consists of a shaft and a hub with permanent magnets arranged to form between two to eight pole pairs that alternate between north and south poles [1-2]. There are multiple magnet materials, such as ferrous mixtures and rareearth alloys. Ferrite magnets are traditional and relatively inexpensive, though rare-earth alloy magnets are becoming increasingly popular because of their high magnetic density. The higher density helps to shrink rotors while maintaining high relative torque when compared to similar ferrite magnets.

BLDC motor consists of an internal shaft position sensor which initiates the control of phase excitation and time of energizing. Conventional DC motor employs mechanical commutator but BLDC motor instead uses electronic commutator for its commutation making BLDC a maintenance-free motor. The two types of BLDC motor are classified based on their shape of back-EMF viz., trapezoidal and sinusoidal 
motors [3-4]. The back EMF of trapezoidal BLDC motor is trapezoidal in shape and to obtain trapezoidal back EMF, the motor should be supplied with a quasi-square wave shaped currents for minimum torque ripple operation.

Figure 1 shows the block diagram of BLDC motor with electronic commutator and logic controller. BLDC is supplied from DC supply and electronic commutator converts the DC supply given to BLDC to AC as commutator in conventional machine. Hall sensors sense the position of the rotor and sends position signal to controller in which control action takes place [5-6]. The controller produces gate pulses to solid-state switches in converter through driver circuit.

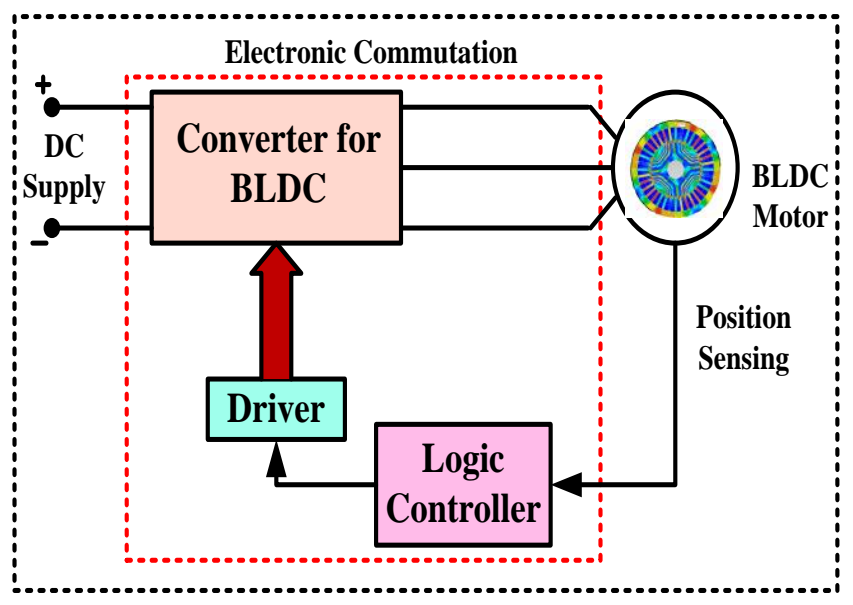

Figure 1.Block diagram of BLDC motor

The DC source to be fed to BLDC motor as an input is chosen to be photo-voltaic (PV) system [7$10]$ in this paper. P-N junction layer arranged in a specific manner forms a PV cell and when photons from solar energy falls on PV cell, electrons in PV cell tries to move crossing the barrier junction giving rise to current flow [11-14].

Solar energy is a type of renewable energy source freely available from universe and the electrical energy generated from this type of resource is inexhaustible. PV system generates DC type of electrical power and is of low voltage. The low voltage output from solar PV system is insufficient to drive any system and thus requires a voltage booster generally a DC-DC converter. Interleaved boost converter is employed in this paper for boosting the low voltage DC output from PV system. The complete schematic arrangement of PV cell Fed BLDC motor is shown in Figure 2.

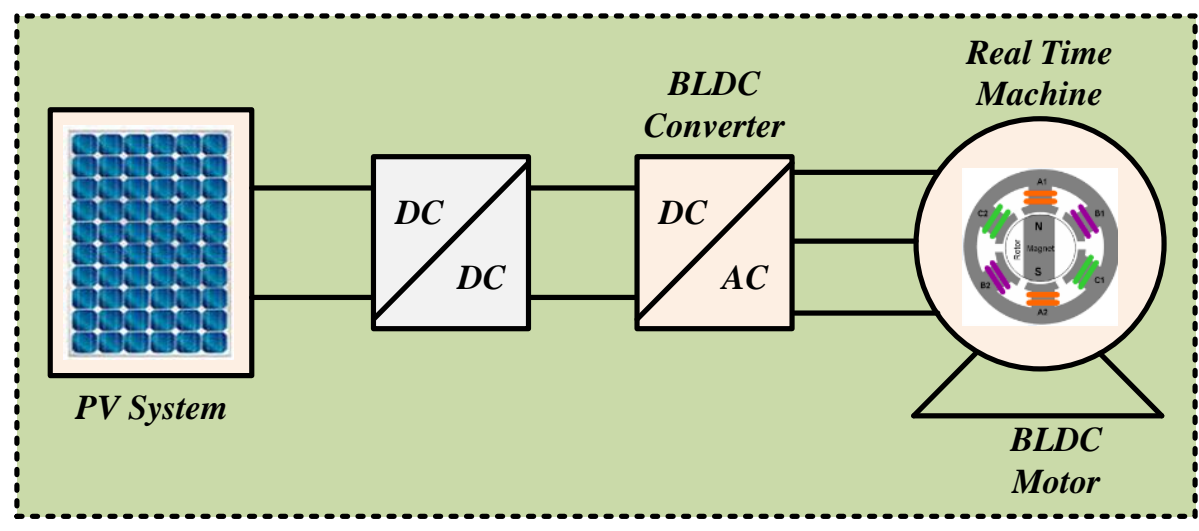

Figure 2. PV cell Fed BLDC motor 
The paper presents an efficient speed control of brushless DC (BLDC) motor drive for solar photovoltaic (PV) system fed system. An interleaved boost converter is employed in the system to boost the solar PV system low output voltage to a level required for the drive system. Interleaved boost converter is operated in closed-loop mode to attain accurate and steady output. Internal current control method is developed and employed for the speed control of PV fed BLDC motor by sensing the actual speed feedback. The appropriateness of the internal current controller for the speed control of PV fed BLDC motor is verified for increamental speed with fixed torque and decreamental speed with fixed torque operating conditions. Also the system with speed control is verified for variable torque condition. The system is developed and results are developed using MATLAB/SIMULINK software.

\section{PV FED CLOSED-LOOP INTERLEAVED BOOST CONVERTER}

The circuit configuration of interleaved DC-DC boost converter is shown in Figure 3. The low voltage DC source is fed to interleaved boost DC-DC converter to rise-up the level of voltage.

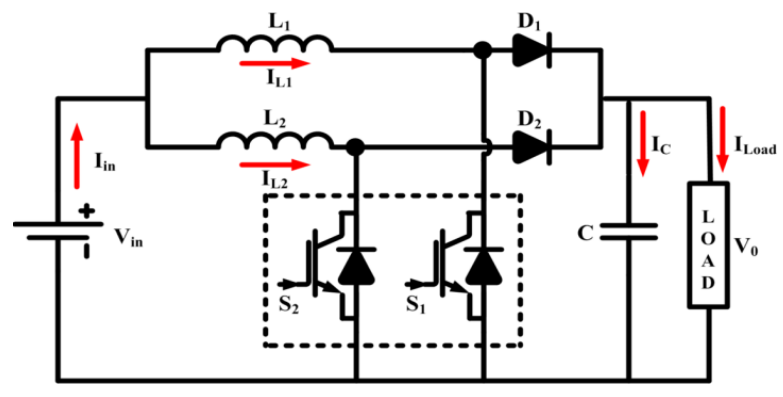

Figure 3. Schematic Diagram of Interleaved DC-DC Boost Converter

The basic schematic diagram of dual-phase interleaved DC-DC converter is depicted in Figure 3. The operating principle of proposed Interleaved DC-DC converter is comprised of two modes, for DG application by using photo-voltaic (PV) system.

Mode I: At position $\mathrm{t}=0$; the switch $\mathrm{S}_{1}$ of first phase is conducted ( $\mathrm{ON}$-state) by gate pulse provided by gate pulse generator. The current at the inductor $\mathrm{L}_{1}$ linearly rising, the switch $\mathrm{S}_{2}$ is at second phase as nonconducted (OFF-state) and the energy stored in inductor $\mathrm{L}_{2}$ is moved to load via phase $\mathrm{L}_{1}$ goes to rise linearly and charging, other side the inductor $\mathrm{L}_{2}$ goes to discharge the energy to load via followed diode $\mathrm{D}_{2}$. The mode of operation during switch $\mathrm{S}_{1}$ of first phase is conducting (ON-state) and switch $\mathrm{S}_{2}$ of second phase is not conducted (OFF-state) is shown in Figure 4 (a).

Mode II: At time $\mathrm{t}=\mathrm{t}_{1}$; the switch $\mathrm{S}_{1}$ of first phase is non-conducting position \& second phase of switch $S_{2}$ is conducted by proper gate pulse generation as shown in Figure 4 (b). The current at inductor $\mathrm{L}_{2}$ is linearly raising, the inductor is to be charged with respect to duty ratio of the switch. At same situation, the switch $S_{1}$ of first phase is un-conducted and the inductor current discharged linearly to load. Transform the stored energy in inductor $t_{1}$, the switch $S_{1}$ is non-conducted or switched OFF. The inductor of other phase $L_{2}$ goes to rise linearly and charging, other side the inductor $L_{1}$ under discharging to load via followed diode $\mathrm{D}_{1}$.

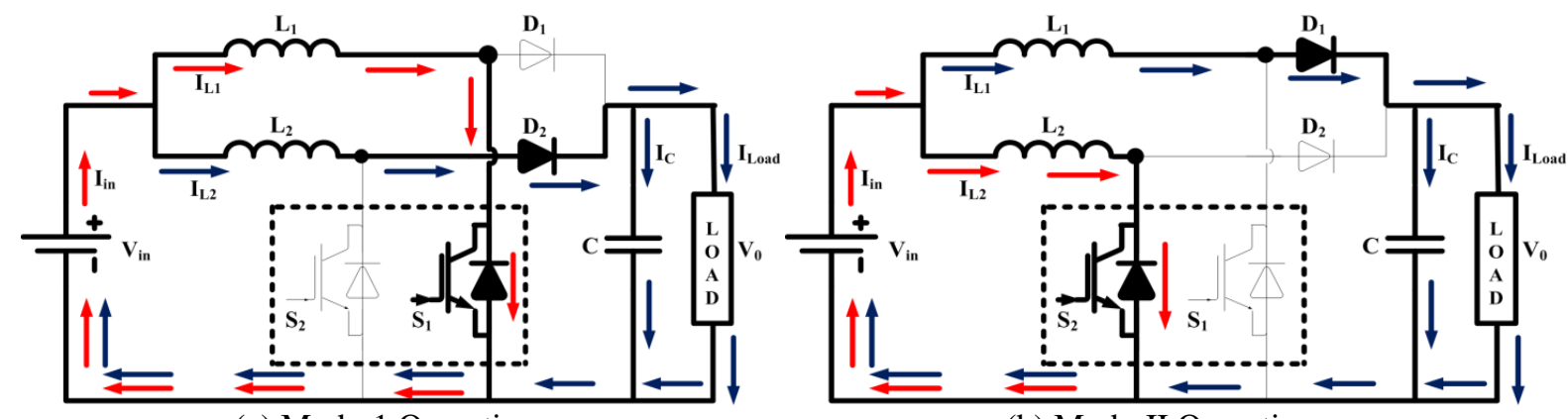

(a) Mode-1 Operation

(b) Mode-II Operation

Figure 4. Modes of operation of interleaved boost converter 
The conventional DC-DC boost converter has more voltage factor, etc. Based on these favourable disadvantages, the formal DC-DC boost converter is replaced by proposed interleaved boost DC-DC converter and used in DG application. The proposed interleaved DC-DC boost converter has been evaluated in recent reliability, modular, low stress, ripple current reduction in both output/input components. Achieving the high efficiency is by replacing the dual circuits into ' $\mathrm{N}$ ' component level, subsequently minimizing the inductor \& $\mathrm{I}^{2} \mathrm{R}$ losses. The ripple component of the input current is reduced by employing the interleaving inductors; makes minimizing the input side filter size would be boost DC-DC converter is generally employed in high rated input current as well, greater input-outcome voltage transformation applications. The dual-phase sequences of the interleaved converter are driven by $180^{\circ}$ out of phase sequences, for this reason the phase shifting is provided. The phase shifting angle is possible as the number of phase sequences.

Photovoltaic devices are rugged and simple in design requiring very little maintenance and their biggest advantage being their construction as stand-alone systems to give outputs from microwatts to megawatts. Hence they are used for power source, water pumping, remote buildings, solar home systems, communications, satellites and space vehicles, reverse osmosis plants, and for even megawatt scale power plants. PV fed interleaved DC-DC boost converter is shown in Figure 5.

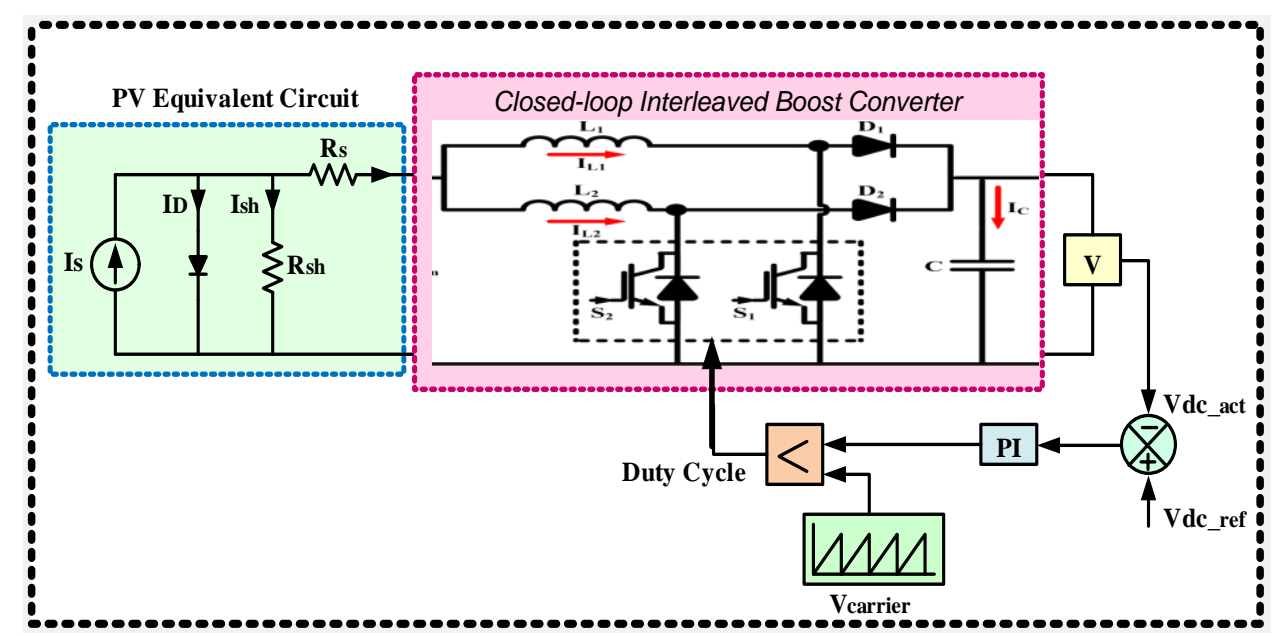

Figure 5. PV fed closed-loop interleaved boost converter

PV system generally produces the output voltage at low voltage level. The low voltage output of PV system is fed to interleaved DC-DC boost converter to boost the voltage at required level. The interleaved boost converter is operated with closed-loop mode of operation to obtain precise output from the converter. The output actual voltage from interleaved boost converter is compared to the reference voltage signal to get the error voltage signal or the short off voltage at the output of the converter. The error in DC output voltage of the converter is fed to PI controller to produce reference signal. The reference signal is logically operated with respect to carrier signal to produce pulses to two power switches of interleaved boost converter.

\section{SPEED CONTROL OF PV FED BLDC DRIVE THROUGH INTERLEAVED BOOST CONVERTER}

Figure 6 shows the speed control strategy of BLDC motor with internal current controller. Primarily, the actual speed of BLDC motor is sensed from hall sensors and is compared to reference speed signal. The error generated from actual and reference speed is fed to a simple PI controller which yields reference torque signal. The obtained reference torque signal is compared with actual torque of BLDC motor and the error is fed through a gain to obtain reference current magnitude, as the current is proportional to torque signal. The obtained current magnitude and the current shape are multiplied to obtain reference current signal. The reference current signal is again compared to actual currents in stator of BLDC motor and the error is fed to hysteresis current controller to produce gate pulses to switches of voltage source converter (VSI). Thus by controlling the current of BLDC motor the speed control is achieved and motor is made to run at desired speed. The overall system with internal current controlled BLDC motor drive supplied with PV fed high voltage gain DC-DC converter is shown in Figure 7. 


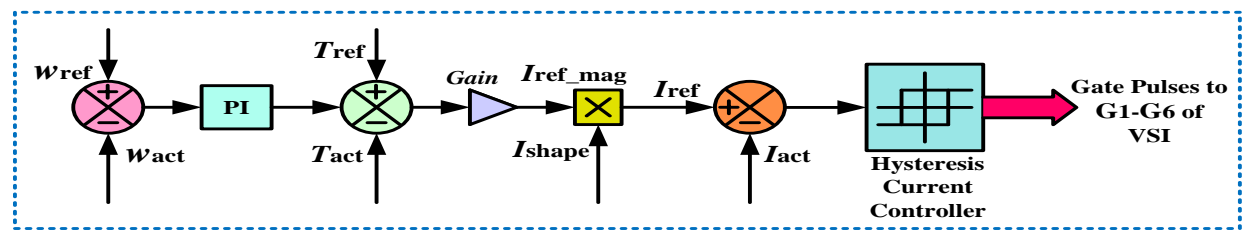

Figure 6. Speed control strategy of BLDC motor with internal current controller

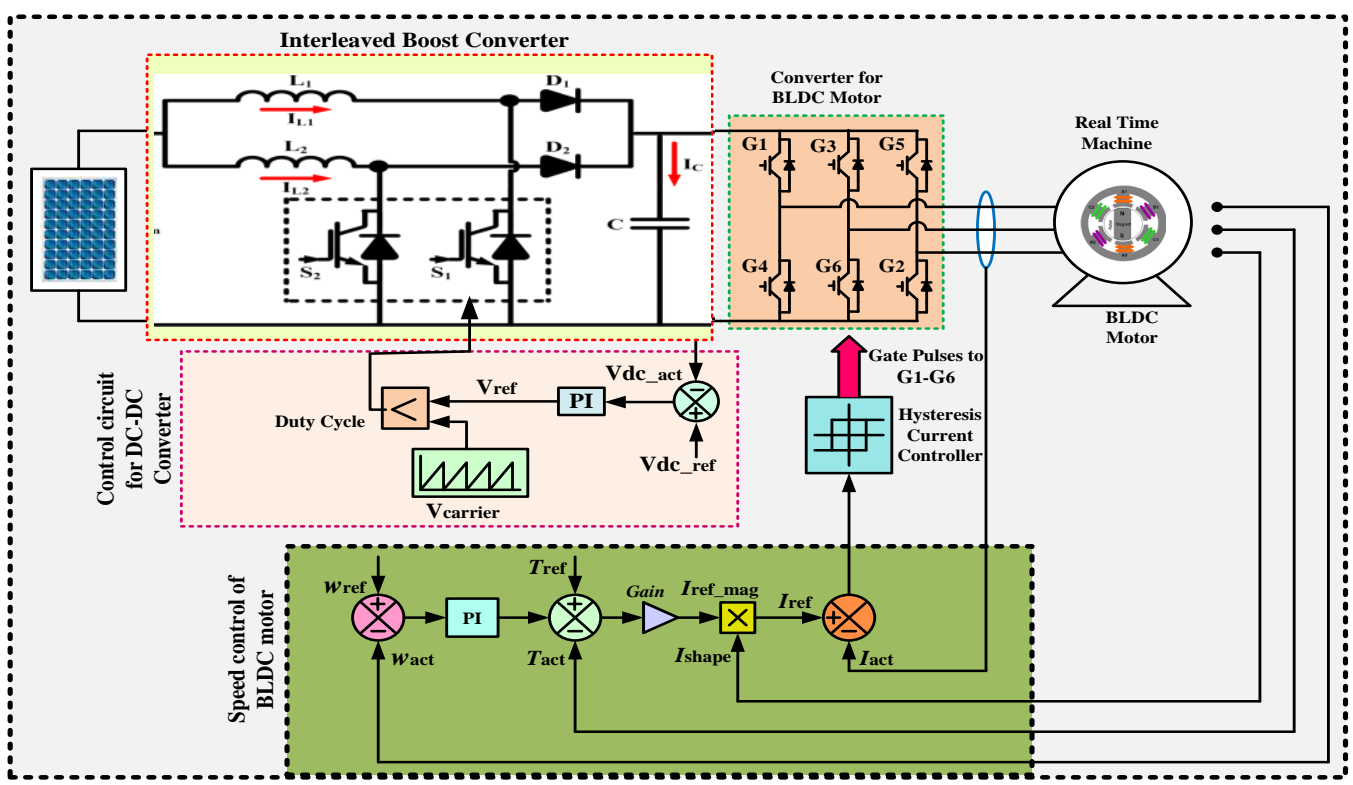

Figure 7. Overall system configuration with internal current controlled BLDC motor drive supplied with PV fed interleaved boost DC-DC converter

\section{RESULTS AND ANALYSIS}

\subsection{BLDC operating at variable increamental speeds with fixed torque condition}

The output voltage from photo-voltaic system is shown in Figure 8. PV yields the output of $200 \mathrm{~V}$ as shown in Figure 9.

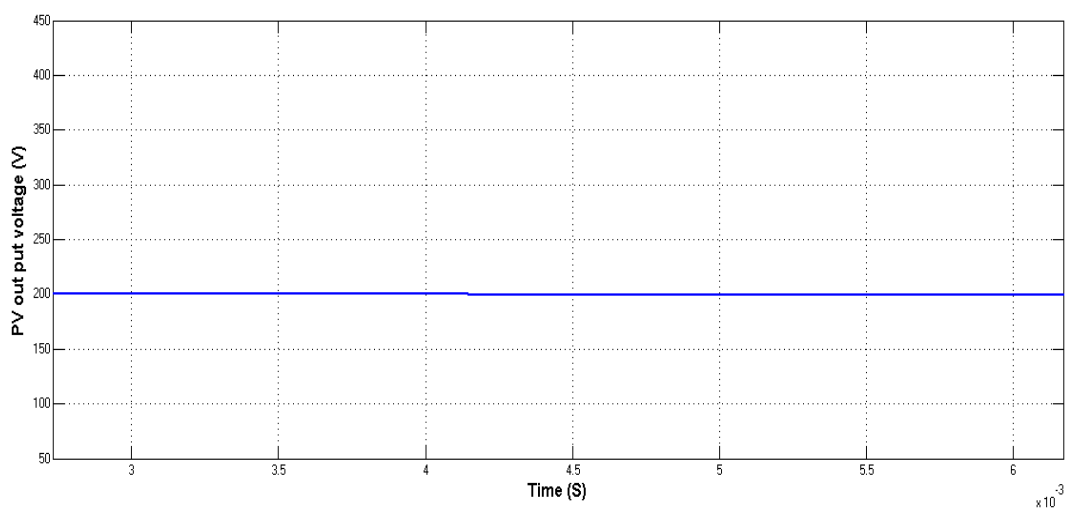

Figure 8. Output voltage from PV

The output voltage from high gain DC-DC converter is shown in Figure 9. DC-DC interleaved boost converter increases the level of PV voltage from $200 \mathrm{~V}$ and gives out the output of $400 \mathrm{~V}$ as shown in figure. Even with speed change command, the output of DC-DC converter is maintained constant.

Solar PV fed non-isolated DC-DC converter for BLDC motor drive with speed control (G. G. Raja Sekhar) 


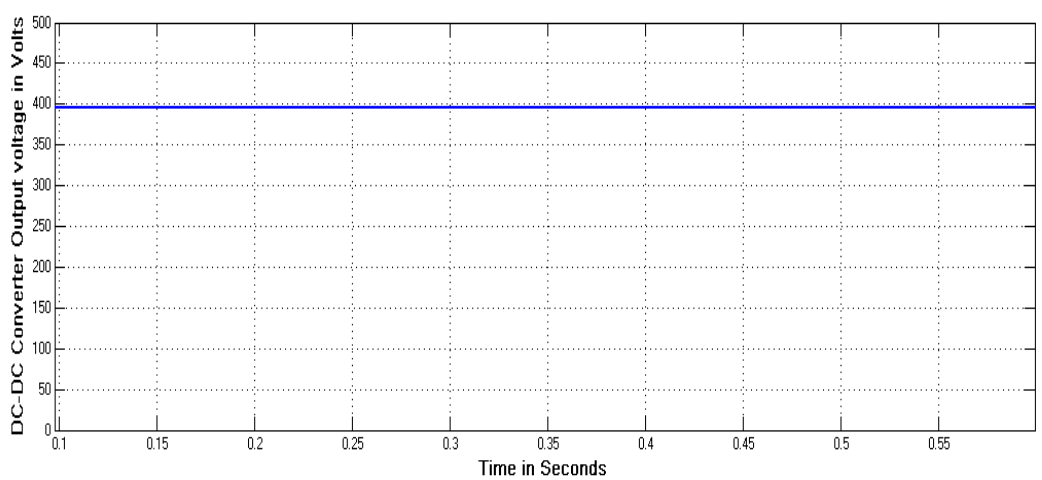

Figure 9. Output voltage from DC-DC converter

Stator current of one phase of BLDC motor and back EMF are shown in Figure 10. Since variable speed command is given at $0.2 \mathrm{sec}$ and $0.4 \mathrm{sec}$, back EMF increase respectively with increase in speed. But the stator current drawn by the BLDC motor remains same with constant magnitude.

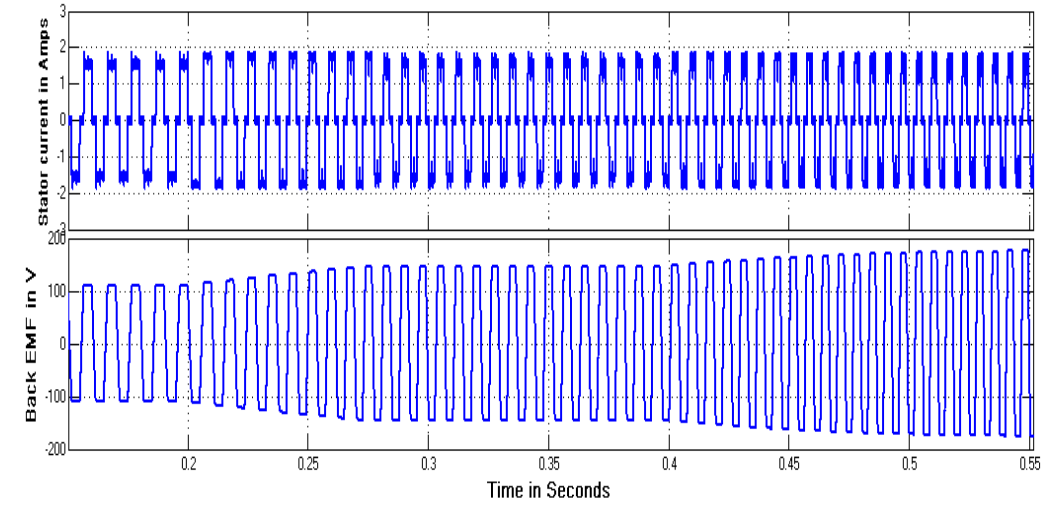

Figure 10. Stator current and back EMF of BLDC motor

Speed of BLDC motor is shown in Figure 11. Since the variable speed condition is applied, the speed changes at $0.2 \mathrm{sec}$ and $0.4 \mathrm{sec}$. Incremental speed command is given at $0.2 \mathrm{sec}$ and at $0.4 \mathrm{sec}$ to be initially at $1500 \mathrm{rpm}$ with change to $2000 \mathrm{rpm}$ at $0.2 \mathrm{sec}$ and $2500 \mathrm{rpm}$ at $0.4 \mathrm{sec}$ respectively and the actual speed follows the set speed command.

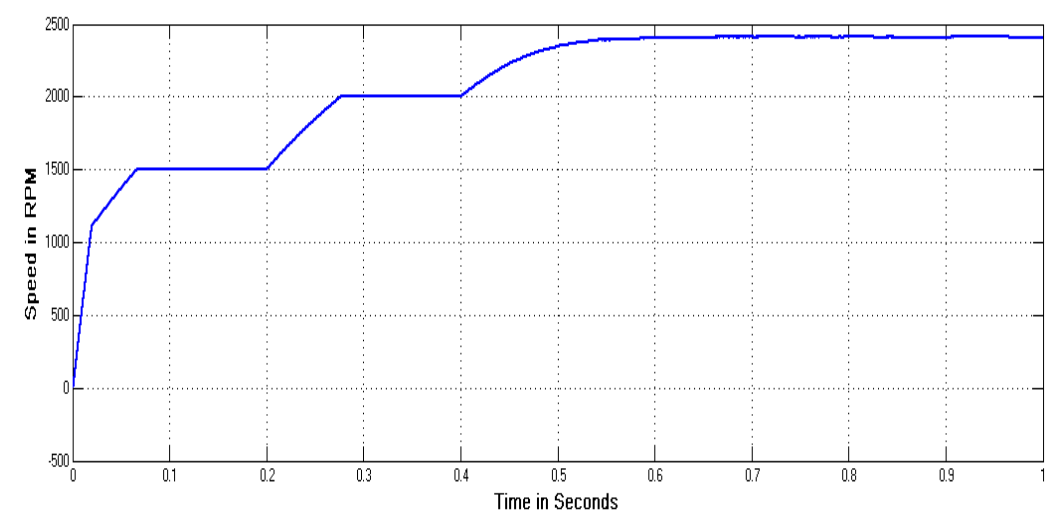

Figure 11. Speed of BLDC motor 
Torque of BLDC motor is shown in Figure 12. Since the variable speed condition is applied, the change of torque is at $0.2 \mathrm{sec}$ and $0.4 \mathrm{sec}$ with respective speed change command but settles soon to final value. Even though, the speed changes torque remains constant apart from fluctuations.

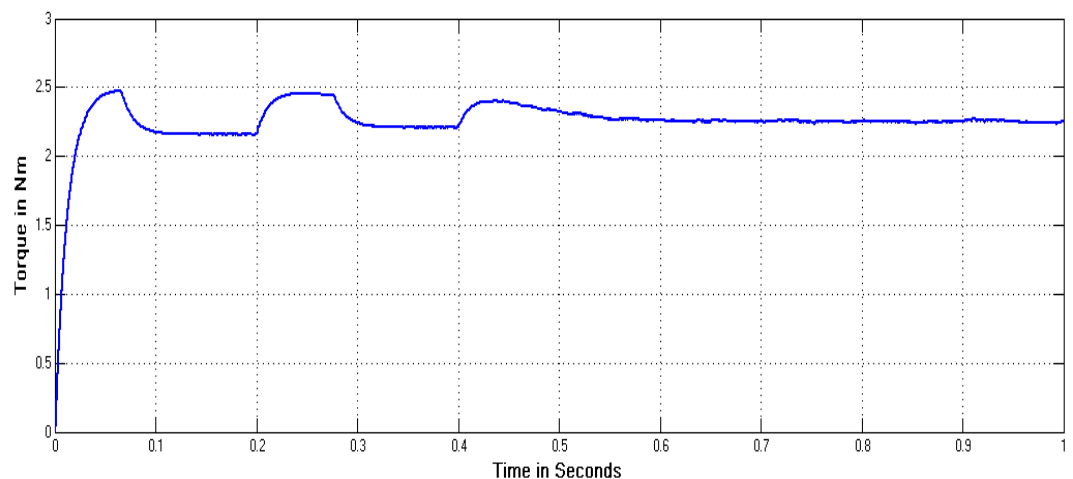

Figure 12. Torque of BLDC motor

\subsection{BLDC operating at variable decreamental speeds with fixed torque condition}

The output voltage from photo-voltaic system is shown in Figure 13. PV yields the output of 200V as shown in Figure 13.

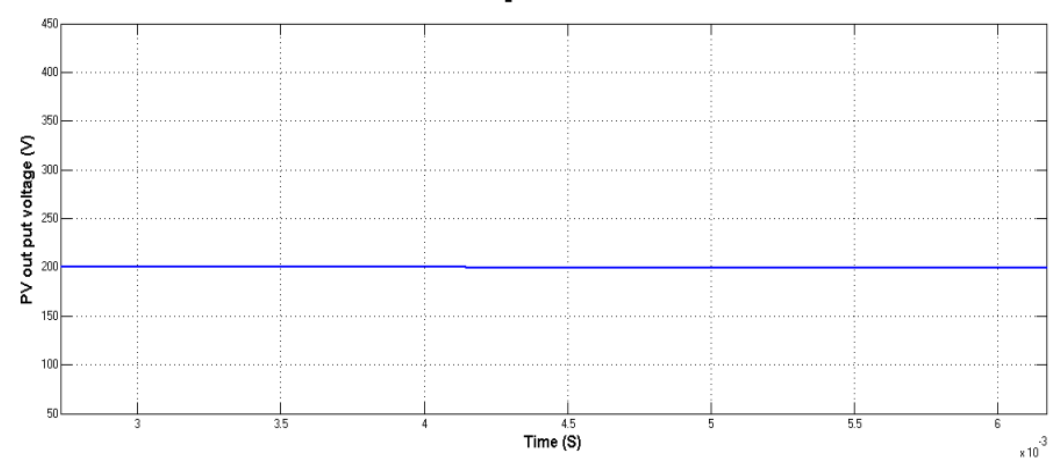

Figure 13. Output voltage from PV

The output voltage from high gain DC-DC converter is shown in Figure 14. DC-DC converter increases the level of PV voltage from $200 \mathrm{~V}$ and gives out the output of $400 \mathrm{~V}$ as shown in figure. Even with speed change command, the output of DC-DC converter is maintained constant.

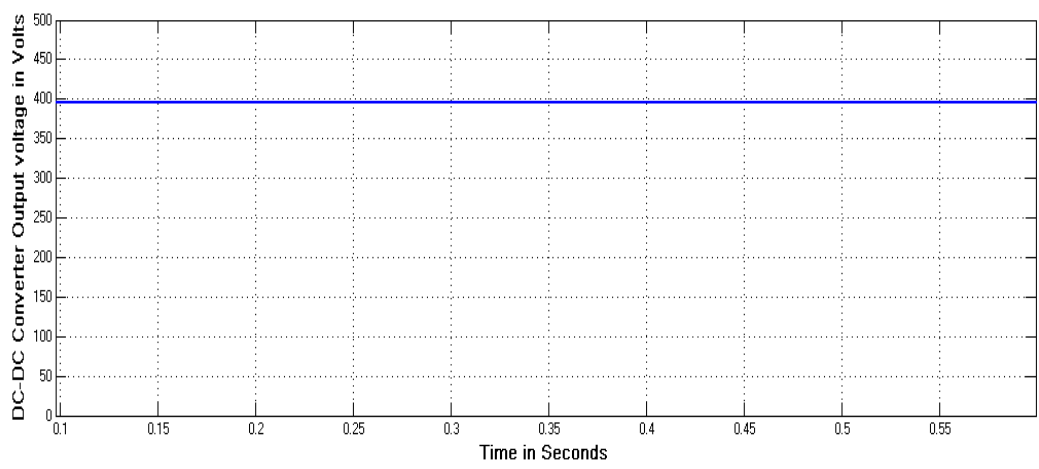

Figure 14. Output voltage from DC-DC converter 
Stator current of one phase of BLDC motor and back EMF are shown in Figure 15. Since variable speed command is given at $0.2 \mathrm{sec}$ and $0.4 \mathrm{sec}$, back EMF decrease respectively with decrease in speed. But the stator current drawn by the BLDC motor remains same with constant magnitude.

Speed of BLDC motor is shown in Figure 16. Since the variable speed condition is applied, the speed changes at $0.2 \mathrm{sec}$ and $0.4 \mathrm{sec}$. Decremental speed command is given at $0.2 \mathrm{sec}$ and at $0.4 \mathrm{sec}$ to be initially at $2500 \mathrm{rpm}$ with change to $2000 \mathrm{rpm}$ at $0.2 \mathrm{sec}$ and $1500 \mathrm{rpm}$ at $0.4 \mathrm{sec}$ respectively and the actual speed follows the set speed command.

Torque of BLDC motor is shown in Figure 17. Since the variable speed condition is applied, the change of torque is at $0.2 \mathrm{sec}$ and $0.4 \mathrm{sec}$ with respective speed change command but settles soon to final value. Even though, the speed changes torque remains constant apart from fluctuations at speed change.

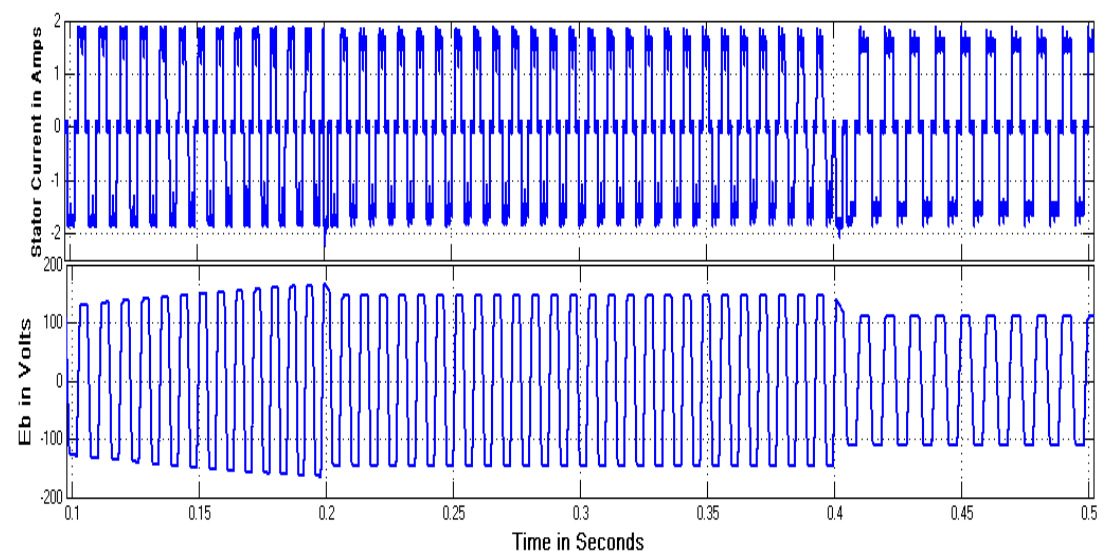

Figure 15. Stator current and back EMF of BLDC motor

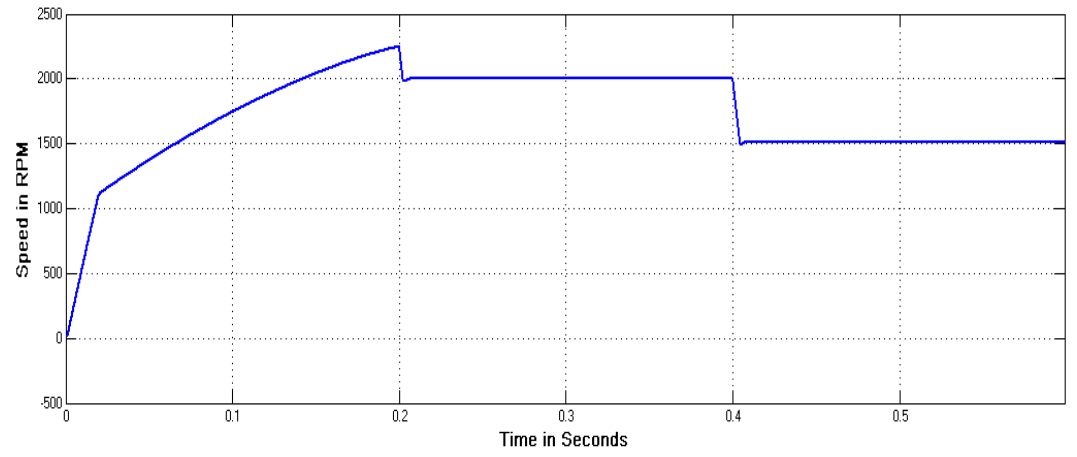

Figure 16. Speed of BLDC motor

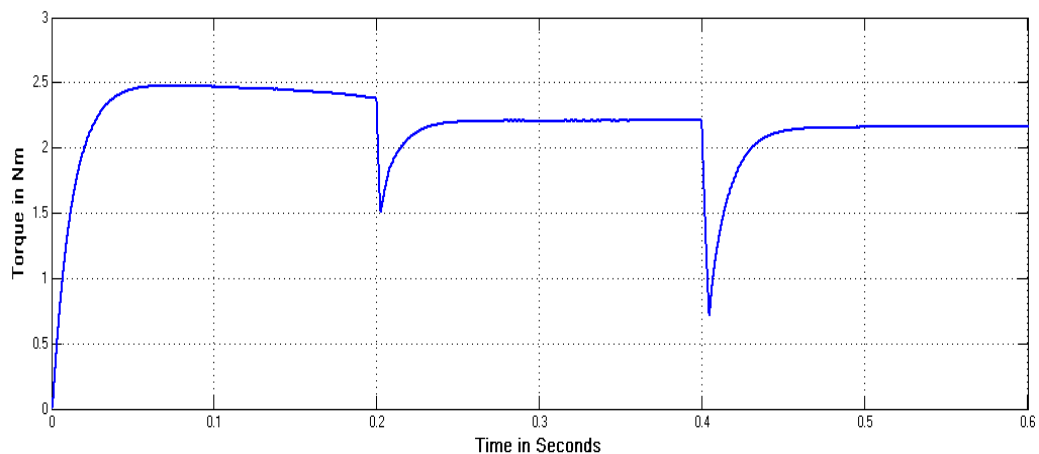

Figure 17. Torque of BLDC motor 


\subsection{BLDC operating at fixed speed with variable torque condition}

The output voltage from photo-voltaic system is shown in Figure 18. PV yields the output of 200V as shown in Figure 18. The output voltage from high gain DC-DC converter is shown in Figure 19. DC-DC converter increases the level of PV voltage from $200 \mathrm{~V}$ and gives out the output of $400 \mathrm{~V}$ as shown in figure. Even with speed change command, the output of DC-DC converter is maintained constant.

Stator current of one phase of BLDC motor and back EMF are shown in Figure 20. Since variable torque command is given at $0.2 \mathrm{sec}$ and $0.4 \mathrm{sec}$, back EMF remains constant but with variation in stator current.

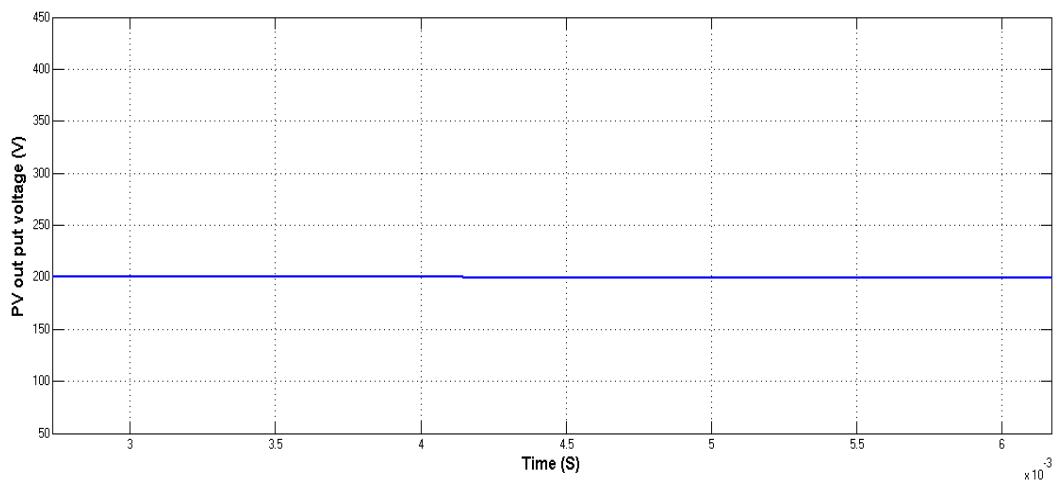

Figure 18. Output voltage from PV

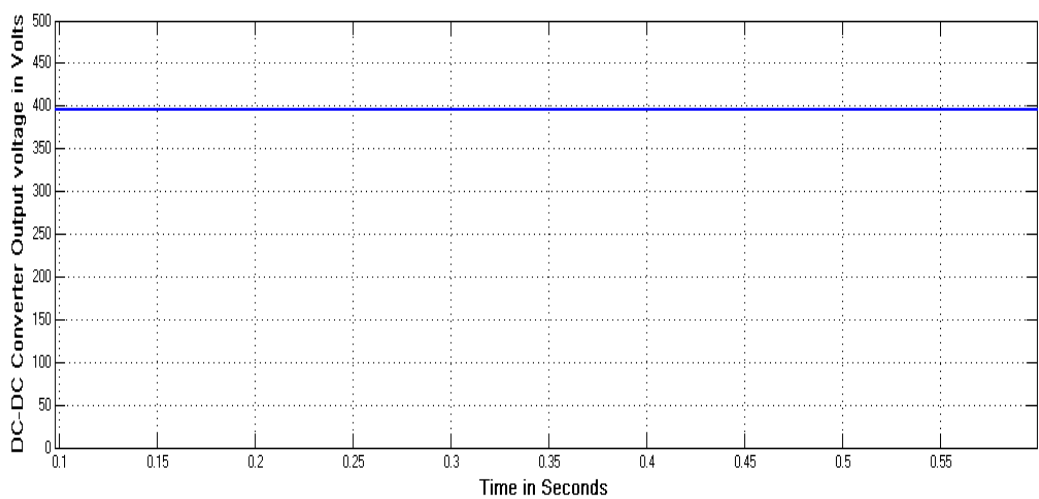

Figure 19. Output voltage from DC-DC converter
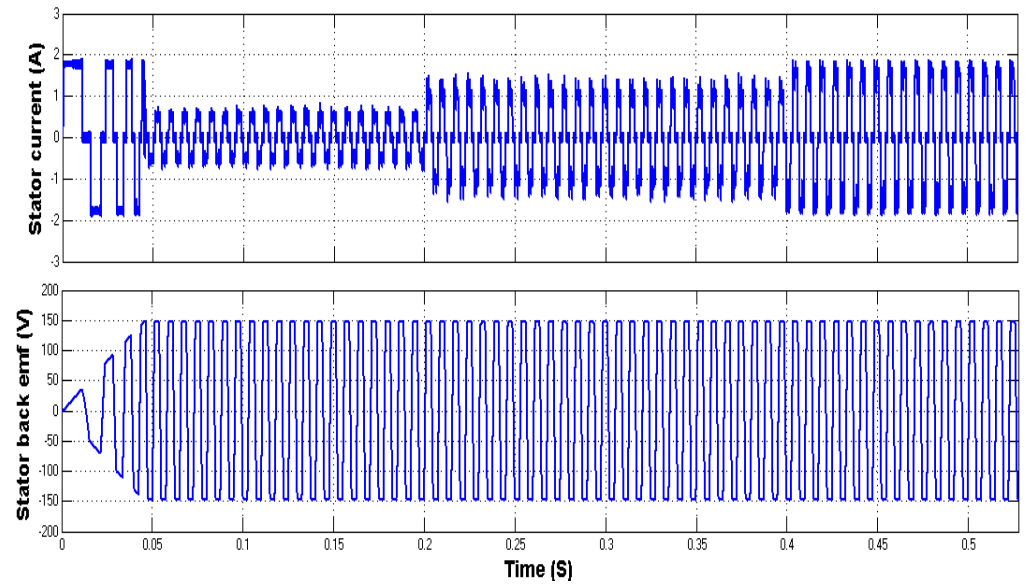

Figure 20. Stator current and back EMF of BLDC motor 
Torque of BLDC motor is shown in Figure 21. Torque variable command is given at $0.2 \mathrm{sec}$ and 0.4 sec and hence the torque varies respectively at that particular time periods.

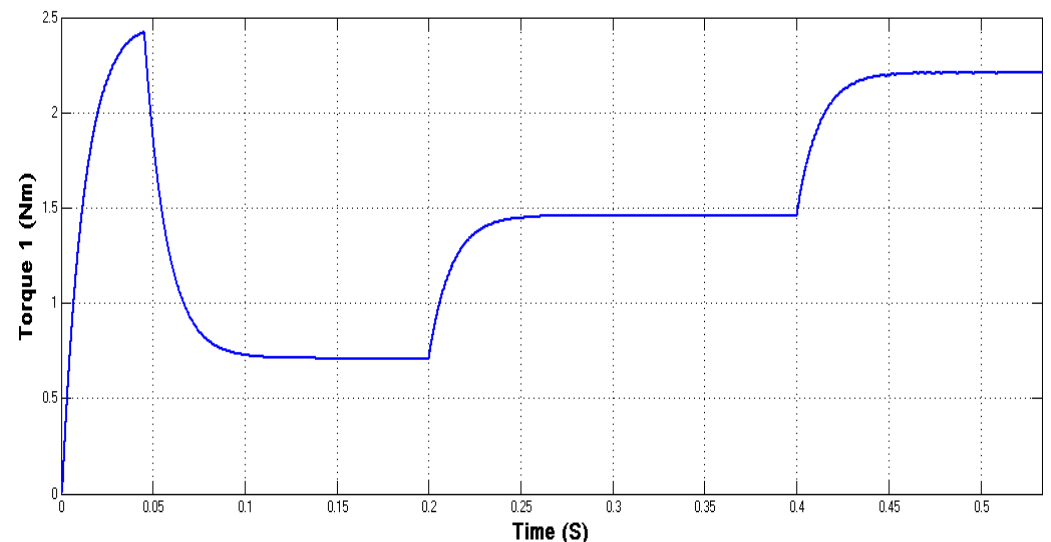

Figure 21. Torque response of BLDC motor

Speed of BLDC motor is shown in Figure 22. The torque is varied with fixed speed condition; the actual speed is unvaried with the change in torque command at respective time periods. This illustrates the speed is controlled with load variation using the proposed speed control. As BLDC is running with variable torque and fixed speed condition and when the torque is varied the result shows it is possible to keep speed fixed or constant.

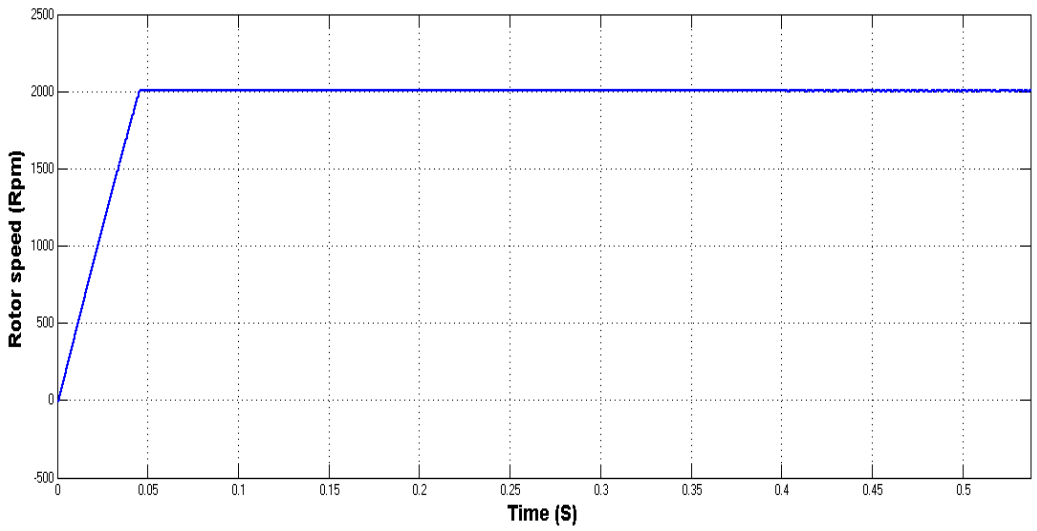

Figure 22. Speed response of BLDC motor

\section{CONCLUSION}

The paper presents an efficient speed control of brushless DC (BLDC) motor drive for photo-voltaic (PV) system fed system. An interleaved boost DC-DC converter is employed in the system to boost the PV system low output voltage $200 \mathrm{~V}$ to a level required for the drive system. Interleaved boost DC-DC converter is operated in closed-loop mode to attain accurate and steady output. The $200 \mathrm{~V}$ output from PV system is stepped up to $400 \mathrm{~V}$ using interleaved boost converter as shown in the result analysis. Internal current control method is developed and employed for the speed control of PV fed BLDC motor. The appropriateness of the internal current controller for the speed control of PV fed BLDC motor is verified for increamental speed with fixed torque and decreamental speed with fixed torque operating conditions and results for respective cases were depicted. With increamental and decremental speed change command issued to BLDC motor yields respective speed changes with fixed torque with the presence of internal current controller keeping the DC output voltage of DC-DC converter constant at 400V. Speed control method is found to be suitable for variable speed conditions maintaining fixed torque. The appropriateness of the internal current controller for 
the speed control of PV fed BLDC motor is verified for fixed speed with variable torque and when the torque is varied the result shows it is possible to keep speed fixed or constant verifying the operation of speed control technique for varying loads.

\section{REFERENCES}

[1] P. K. Sharma and A. S. Sindekar, "Performance analysis and comparison of BLDC motor drive using PI and FOC," 2016 International Conference on Global Trends in Signal Processing, Information Computing and Communication (ICGTSPICC), Jalgaon, India, 2016, pp. 485-492.

[2] V. Ramesh, Y. Kusuma Latha, "An Interleaved Boost Converter Based PFC Control Strategy for BLDC motor," International Journal of Electrical and Computer Engineering (IJECE), Vol. 5, No. 5, October 2015, pp. 957 966.

[3] T. Raghu, S. Chandra Sekhar, J. Srinivas Rao, "SEPIC Converter based-Drive for Unipolar BLDC Motor," International Journal of Electrical and Computer Engineering (IJECE), Vol.2, No.2, April 2012, pp. 159 165.

[4] Lei Jin-li, "Adaptive Control for Brushless DC Motor Based on Fuzzy Inference," TELKOMNIKA Indonesian Journal of Electrical Engineering, Vol.12, No.5, May 2014, pp. 3392 3398.

[5] C. Bharatiraja, Shyam Babu, V. Krishnakumar, P. Sanjeevikumar, Nixon George, "Investigation of Slim Type BLDC Motor Drive with Torque Ripple Minimization using Abridged Space-Vector PWM Control Method," International Journal of Power Electronics and Drive System (IJPEDS) Vol. 8, No. 2, June 2017, pp. 593 600.

[6] D. Kamalakannan, N. J. Singh, M. Karthi, V. Narayanan and N. S. Ramanathan, "Design and development of DC powered BLDC motor for Mixer-Grinder application," 2016 First International Conference on Sustainable Green Buildings and Communities (SGBC), Chennai, 2016, pp. 1-6.

[7] M. K. Kim, H. S. Bae and B. S. Suh, "Comparison of IGBT and MOSFET inverters in low-power BLDC motor drives," 2006 37th IEEE Power Electronics Specialists Conference, Jeju, 2006, pp. 1-4.

[8] A. Bag, B. Subudhi and P. K. Ray, "Grid integration of PV system with active power filtering," 2nd International Conference on Control, Instrumentation, Energy \& Communication (CIEC), Kolkata, 2016, pp. 372-376

[9] D. Noel, F. Sozinho, D. Wilson and K. Hatipoglu, "Analysis of large scale photovoltaic power system integration into the existing utility grid using PSAT," SoutheastCon 2016, Norfolk, VA, 2016, pp. 1-7.

[10] V. S. Bugade and P. K. Katti, "Dynamic modelling of microgrid with distributed generation for grid integration," International Conference on Energy Systems and Applications, Pune, 2015, pp. 103-107.

[11] N. Eghtedarpour, E. Farjah, Control strategy for distributed integration of photovoltaic and energy storage systems in DC micro-grids, Renewable Energy (Elsevier), Volume 45, September 2012, Pages 96-110

[12] R. Kumar and B. Singh, "BLDC Motor-Driven Solar PV Array-Fed Water Pumping System Employing Zeta Converter," in IEEE Transactions on Industry Applications, vol. 52, no. 3, pp. 2315-2322, May-June 2016

[13] M. Ouada M. S. Meridjet N. Talbi "Optimization photovoltaic pumping system based BLDC using fuzzy logic MPPT control" Proc. Int. Renew. Sustain. Energy Conf. (IRSEC) pp. 27-31 Mar. 2013.

[14] A. Terki A. Moussi A. Betka N. Terki "An improved efficiency of fuzzy logic control of PMBLDC for PV pumping system" Appl. Math. Mo 